\title{
The effects of general and spinal anesthesia on systemic inflammatory response in patients undergoing total knee arthroplasty
}

\author{
Total diz artroplastisi uygulanan hastalarda genel ve spinal anestezinin \\ sistemik inflamatuvar yanıt üzerine etkileri
}

\begin{abstract}
Mehmet Eroğlu, MD., Serdar Kokulu, MD., ${ }^{2}$ Halit Buğra Koca, PhD., ${ }^{3}$ Mehmet Ersegün Demirboğan, MD. ${ }^{2}$ Elif Doğan Baki, MD., ${ }^{2}$ Özal Özcan, MD. ${ }^{1}$

'Department of Orthopedics and Traumatology, Medical Faculty of Afyon Kocatepe University, Afyonkarahisar, Turkey

${ }^{2}$ Department of Anesthesiology and Reanimation, Medical Faculty of Afyon Kocatepe University, Afyonkarahisar, Turkey

${ }^{3}$ Department of Medical Biochemistry, Medical Faculty of Afyon Kocatepe University, Afyonkarahisar, Turkey
\end{abstract}

\begin{abstract}
Objectives: This study aims to compare the systemic inflammatory responses (SIRs) developing after total knee arthroplasty (TKA) performed under general or spinal anesthesia.
\end{abstract}

Patients and methods: This prospective study included 40 patients ( 8 males, 32 females; mean age $67.15 \pm 9.27$ years; range 51 to 89 years) who underwent TKA in our clinic between February 2014 and July 2014. Patients were grouped to receive general (group 1, $\mathrm{n}=20$ ) or spinal anesthesia (group 2, $\mathrm{n}=20$ ). Levels of pro-inflammatory markers [Interleukin-6 (IL-6), IL-8, IL-1 $\beta$, tumor necrosis factor-alpha (TNF- $\alpha$ ) and C-reactive protein (CRP)] were studied from the venous blood samples obtained immediately before induction to anesthesia $\left(\mathrm{T}_{1}\right)$, immediately after closure of the operative wound $\left(\mathrm{T}_{2}\right)$, and at 24 hours postoperatively $\left(\mathrm{T}_{3}\right)$.

Results: In both groups, levels of CRP and IL-6 were significantly increased at $\mathrm{T}_{3}$ compared to those achieved at $\mathrm{T}_{1}$. Changes in the levels of TNF- $\alpha$ in both groups were similar. There were no significant differences between the groups in terms of the changes within the levels of the studied markers at the respective time intervals.

Conclusion: According to our study results, SIRs developing after TKA performed under general or spinal anesthesia are similar.

Keywords: General anesthesia; inflammatory response; spinal anesthesia; surgery; total knee arthroplasty.

\section{$\ddot{O Z z}$}

Amaç: Bu çalışmada genel veya spinal anestezi altında uygulanan total diz artroplastisi (TDA) sonrasında ortaya çıkan sistemik inflamatuvar yanıt (SIY)'lar karşılaştırıldi.

Hastalar ve yöntemler: Bu prospektif çalışmaya Şubat 2014 - Temmuz 2014 tarihleri arasında kliniğimizde TDA uygulanan 40 hasta (8 erkek, 32 kadın; ort. yaş $67.15 \pm 9.27$ yıl; dağılım 51-89 yıl) dahil edildi. Hastalar genel (grup 1, n=20) ve spinal (grup 2, n=20) anestezi alacak şekilde gruplandırıldı. Pro-inflamatuvar belirteçlerin [interlökin-6 (IL-6), IL-8, IL-1 $\beta$, tümör nekroz faktör-alfa $(\mathrm{TNF}-\alpha)$ ve C-reaktif protein (CRP)] düzeyleri anestezi indüksiyonunun hemen öncesinde $\left(\mathrm{T}_{1}\right)$, ameliyat yarasının kapatılmasından hemen sonra $\left(\mathrm{T}_{2}\right)$ ve ameliyat sonrası 24. saatte alınan venöz kan örneklerinden çalışıldı.

Bulgular: Her iki grupta CRP ve IL-6 düzeyleri $\mathrm{T}_{1}$ 'de elde edilenlere kıyasla $\mathrm{T}_{3}$ 'te anlamlı düzeyde arttı. Her iki grupta TNF- $\alpha$ düzeylerindeki değişiklikler benzerdi. İlgili zaman aralıklarında çalışılan belirteç düzeylerindeki değişiklikler açısından iki grup arasında anlamlı farklılıklar yoktu.

Sonuç: Çalışma sonuçlarımıza göre, genel veya spinal anestezi altında uygulanan TDA sonrasında ortaya çıkan SIY'lar benzerdir.

Anahtar sözcükler: Genel anestezi; inflamatuvar yanıt; spinal anestezi; cerrahi; total diz artroplastisi.

- Received: May 20, 2016 Accepted: September 29, 2016

- Correspondence: Mehmet Eroğlu, MD. Afyon Kocatepe Üniversitesi Tıp Fakültesi Ortopedi ve Travmatoloji Anabilim Dalı, 03200 Afyonkarahisar, Turkey, Tel: +90 535 - 6652031 Fax: +90 272 - 2463300 e-mail: meroglufb@gmail.com 
Total knee arthroplasty (TKA), with its proven longterm success, constitutes the standard treatment of choice in end-stage gonarthrosis. ${ }^{[1]}$ Total knee arthroplasty is a major surgery and it is well-known that the extent of surgical trauma may influence systemic inflammatory response (SIR). The SIR induced by TKA may lead to increased postoperative complication rates. Anesthesia, also, was reported to contribute to SIR. ${ }^{[2]}$ Considering the extent of surgical trauma, the effect of anesthesia on SIR may be of importance following TKA.

Inflammation is essential for tissue reconstruction. However, excessive SIR can have hazardous effects which lead to postoperative complications, such as postoperativeinfections, wound healing disturbances, prolonged hospital stay, increased health costs or organ dysfunctions. ${ }^{[2,3]}$ Total knee arthroplasty might induce an increased SIR compared to some minor surgeries. Therefore, to prevent morbidity, it is important to reduce excessive SIR induced by TKA and anesthetic methods. The severity and duration of surgical trauma, patients' age, and anesthetic methods may influence perioperative stress response..$^{[4-9]}$ Anesthesia maintains homeostasis, makes the operation painless, reduces excessive response to surgery, and modulates immune responses. ${ }^{[10]}$ In addition, anesthetics influence cellular (the functions of immune competent cells) and humoral (inflammatory mediator gene expression and secretion) inflammatory responses. ${ }^{[11]}$ Different anesthetic methods may affect the cytokine response to surgery; e.g. addition of spinal block reduces neuroendocrinal response to surgery compared to general anesthesia alone. ${ }^{[2,12]}$ Moreover, regional anesthesia was reported to have less adverse effects than general anesthesia. ${ }^{[2]}$

To the best of our knowledge, few studies in the literature investigated the effects of general vs. spinal anesthesia on the SIR induced by TKA. Therefore, in this study, we aimed to compare the SIRs developing after TKA performed under general or spinal anesthesia.

\section{PATIENTS AND METHODS}

This prospective study included 40 patients ( 8 males, 32 females; mean age $67.15 \pm 9.27$ years; range 51 to 89 years) who underwent TKA in Medical Faculty of Afyon Kocatepe University between February 2014 and July 2014 with an American Society of Anesthesiologists score of 1-3. Patients were informed about the study procedure and provided written consent. The study protocol was approved by the Afyon Kocatepe University Ethics Committee. The study was conducted in accordance with the principles of the Declaration of Helsinki.

Appropriate patients were assigned to receive general (group 1, n=20) or spinal anesthesia (group 2, n=20). Patients with a history of metabolic or immunological diseases and use of immune suppressive drugs were excluded. All patients were operated by the same surgeon using the same surgical method and a tourniquet was used during the surgery.

In group 1, intravenous (IV) midazolam (2 mg), propofol $(2 \mathrm{mg} / \mathrm{kg})$, and fentanyl $(1.5 \mu \mathrm{g} / \mathrm{kg})$ were used for induction. Patients received IV rocuronium $(0.8 \mathrm{mg} / \mathrm{kg})$ to facilitate endotracheal intubation. After intubation, anesthesia was maintained with air and

TABLE I

Demographic and intraoperative data of general vs. spinal anesthesia groups

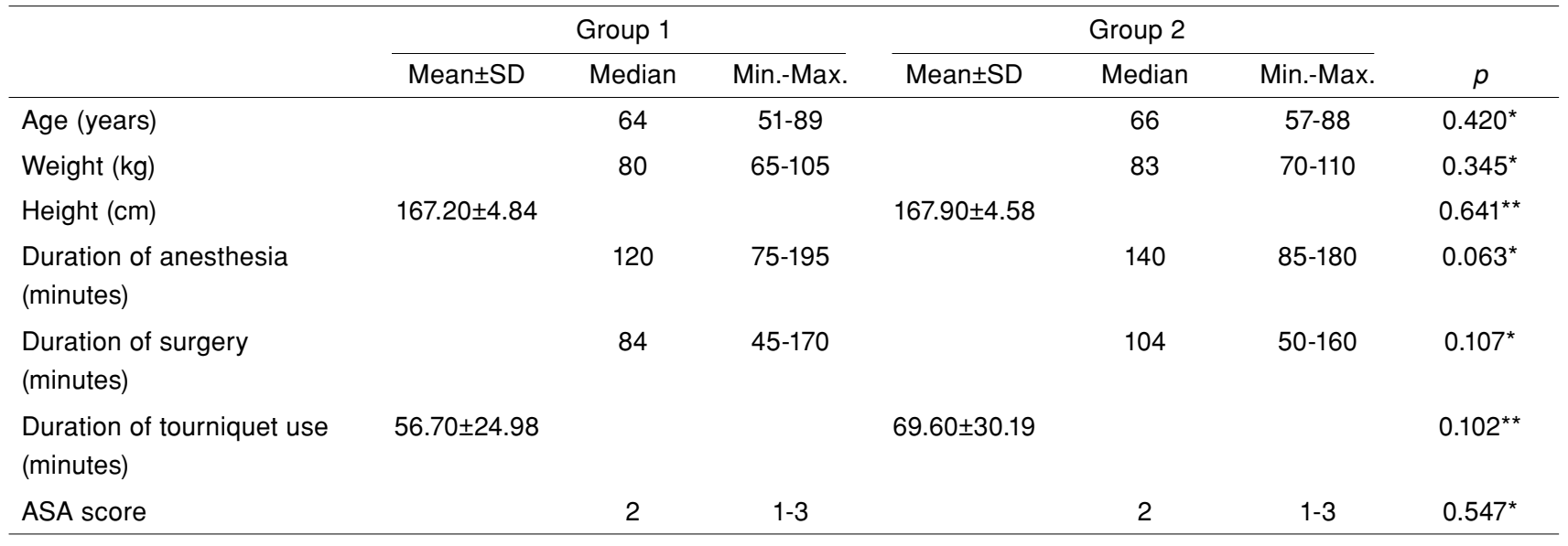

SD: Standard deviation; Min.: Minimum; Max.: Maximum; ASA: American Society of Anesthesiologists. * Mann-Whitney U-test was used for binary comparison between groups. ${ }^{* *}$ Independent samples t-test was used for binary comparison between groups. 
desflurane $(6 \%)$ mixture and rocuronium $(0.15 \mathrm{mg} / \mathrm{kg})$ to maintain muscle relaxation. In group 2, 500 mL Ringer's lactate was given intravenously before spinal anesthesia. Spinal block was performed with the patients seated and bupivacaine $0.5 \%$ (3-4 mL) injected through L3-L4 intervertebral space using a 25 gauge spinal needle.

Patient characteristics and perioperative events (total blood loss, durations of anesthesia, surgery, and tourniquet use) were recorded. Routine monitorization was administered for all patients. Crystalloids were used for hydration when clinically needed. No patients required blood transfusion. All patients in both groups received the same analgesics postoperatively.

To evaluate the SIR, venous blood samples were obtained from all patients immediately before induction to anesthesia $\left(\mathrm{T}_{1}\right)$, immediately after closure of the operative wound $\left(\mathrm{T}_{2}\right)$, and at 24 hours postoperatively $\left(\mathrm{T}_{3}\right)$. Levels of interleukin-6 (IL-6), IL-8, interleukin-1 beta (IL-1 $\beta$ ), tumor necrosis factoralpha (TNF- $\alpha$ ), and C-reactive protein (CRP) were studied. These pro-inflammatory markers were selected from previous studies in the literature because of rapid response. ${ }^{[13]}$ Venous blood samples $(4 \mathrm{~mL})$ were centrifuged at $5000 \mathrm{rpm}$ for 10 minutes immediately after collection and plasma aliquots were stored at $-20{ }^{\circ} \mathrm{C}$ until assayed. Plasma concentrations of IL-6, IL-8, IL-1 $\beta$, and TNF- $\alpha$ were measured using eBioscience Human Platinum enzyme-linked immunosorbent assay kits (Bender MedSystems $\mathrm{GmbH}$, Vienna, Austria). Absorbance detection was performed using ChemWell ${ }^{\circledast} 2910$ Analyzer (Awareness Technology, Inc. Martin Hwy. Palm City, USA). The results were given as $\mathrm{pg} / \mathrm{mL}$.

Values of CRP, IL-6, IL-8, IL-1 $\beta$, and TNF- $\alpha$ were compared with the patients divided into subgroups of body mass index ( $<30$ vs. $>30)$, duration of anesthesia ( $<130$ vs. $>130$ minutes), duration of surgery ( $<90$ vs. $>90$ minutes), and patients' age ( $<65$ vs. $>65$ years).

\section{Statistical analysis}

We estimated the sample size regarding the power analysis. For two tailed $\alpha$ value of 0.05 (sensitivity: 95\%) and a $\beta$ value of 0.20 (study power: $80 \%$ ),

TABLE II

\begin{tabular}{|c|c|c|c|c|}
\hline & $\mathrm{T}_{1}$ & $\mathrm{~T}_{2}$ & $\mathrm{~T}_{3}$ & $p$ \\
\hline \multicolumn{5}{|l|}{ C-reactive protein } \\
\hline Group 1 & $0.68(0.46)$ & $0.67(0.76)$ & $11.29 \pm 6.20^{\dagger, \neq, a, b}$ & $<0.001$ \\
\hline Group 2 & $0.34(0.65)$ & $0.54(0.47)$ & $12.20 \pm 4.13^{t, \ddagger, a, b}$ & $<0.001$ \\
\hline$P$ value inter-group & $0.27^{\star}$ & $0.85^{\star}$ & $0.59^{\star *}$ & \\
\hline \multicolumn{5}{|l|}{ IL-1 beta } \\
\hline Group 1 & $1.96(3.67)$ & $1.90(2.65)$ & $2.66(2.54)^{\mathrm{t}, \pm}$ & 0.09 \\
\hline Group 2 & $1.8(2.02)$ & $1.68(2.31)$ & $2.08(1.91)^{\dagger, \ddagger}$ & 0.11 \\
\hline$P$ value inter-group & $0.19^{*}$ & $0.94^{*}$ & $0.93^{*}$ & \\
\hline \multicolumn{5}{|l|}{ IL-6 } \\
\hline Group 1 & $2.97(3.84)$ & $2.06(2.29)$ & $63.54 \pm 30.32^{\dagger, \neq a, b}$ & $<0.001$ \\
\hline Group 2 & $2.22(3.37)$ & 3.05 (4.59) & $70.86 \pm 27.21^{\dagger, \ddagger a, b}$ & $<0.001$ \\
\hline$P$ value inter-group & $0.39^{*}$ & $0.56^{*}$ & $0.43^{* *}$ & \\
\hline IL-8 & $11.7(7.44)$ & $9.8(18.65)$ & $17.24(19.35)^{\mathrm{t}, \neq}$ & 0.52 \\
\hline Group 1 & $10.66(13.08)$ & $12.66(26.55)$ & $22.23(19.24)^{\mathrm{t}, \neq}$ & 0.14 \\
\hline \multicolumn{5}{|l|}{ Group 2} \\
\hline$P$ value inter-group & $0.18^{*}$ & $0.78^{*}$ & $0.84^{*}$ & \\
\hline \multicolumn{5}{|l|}{ TNF-alpha } \\
\hline Group 1 & $2.12(4.11)$ & $2.86(4.09)$ & $2.08(3.17)^{\dagger, \ddagger}$ & 0.19 \\
\hline Group 2 & $2.38(2.82)$ & $1.56(3.39)$ & $1.49(2.71)^{\dagger, \ddagger}$ & 0.39 \\
\hline$P$ value inter-group & $0.48^{*}$ & $0.29^{*}$ & $0.40^{*}$ & \\
\hline
\end{tabular}

* Mann-Whitney U test was used for binary comparison between groups. Data are given as median (minimum-maximum). ${ }^{\star \star}$ Independent samples $\mathrm{t}$-test was used for binary comparison between groups. Data are given as mean \pm standard deviation. $\dagger$ Friedman test was used to compare values obtained within same groups at $T_{1}, T_{2}$ and $T_{3}$. $\neq$ Wilcoxon test was used for binary comparisons within same group. The data are given as median (min.-max.) unless otherwise stated. Bold $p$ values define significant difference between two groups $(p<0.05),\left(a ; p<0.05\right.$ vs. $T_{1}, b ; p<0.05$ vs. $\left.T_{2}\right)$ IL: Interleukin; $\mathrm{T}_{1}$ : Immediately before induction to anesthesia; $\mathrm{T}_{2}$ : Immediately after wound closure; $\mathrm{T}_{3}$ : 24 hours postoperatively; TNF: Tumor necrosis factor. 


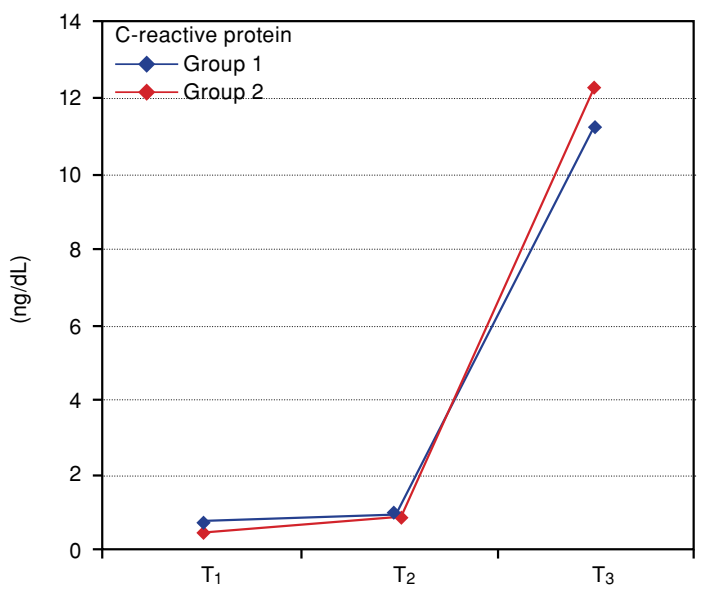

Figure 1. Mean levels of C-reactive protein in two groups achieved at three different time periods $\left(\mathrm{T}_{1}, \mathrm{~T}_{2}\right.$, and $\left.\mathrm{T}_{3}\right)$.

we detected that at least 20 patients were needed for each group.

The IBM SPSS software version 20.0 (IBM Corporation, Armonk, NY, USA) was used for statistical analysis. The distribution of variables was evaluated with the Shapiro-Wilk test. Variables with normal distribution were expressed as mean $( \pm)$ standard deviation and the ones without normal distribution were expressed as median (minimum-maximum). Student's t test was used to compare parametric variables between the groups. Friedman test was used to compare the values obtained within the same groups at $\mathrm{T}_{1}, \mathrm{~T}_{2}$, and $\mathrm{T}_{3}$. Wilcoxon signed ranks test was used to evaluate continuous variables with normal distribution for the same groups. $P$ value of $<0.05$ was considered statistically significant.

\section{RESULTS}

There were no statistically significant differences between demographic and intraoperative data of both groups (Table I). Comparison of the changes in the studied parameters within and between the groups at three different time points $\left(T_{1}, T_{2}\right.$, and $\left.T_{3}\right)$ are given in Table II. In groups 1 and 2, levels of CRP and IL-6 increased significantly and in parallel at $T_{3}$ when compared to values achieved at $\mathrm{T}_{1}(\mathrm{p}<0.001)$. Although the increase from $T_{1}$ to $T_{2}$ was not significant, the increase from $T_{2}$ to $T_{3}$ was (Table II) (Figures 1 and 2). Changes in the levels of IL-1 $\beta$, IL- 8 , and TNF- $\alpha$ were similar in both groups with no statistically significant differences ( $p>0.05$ ) (Table II). Mean level of IL-1 $\beta$ from $\mathrm{T}_{1}$ to $\mathrm{T}_{2}$ was observed to decrease in group 1 and to increase in group 2. However, the difference between the groups was not significant and final levels of IL-1 $\beta$ at $T_{3}$ were similar with no differences $(p>0.05)$ (Table II) (Figure 2). Level of IL-8 gradually increased (a)

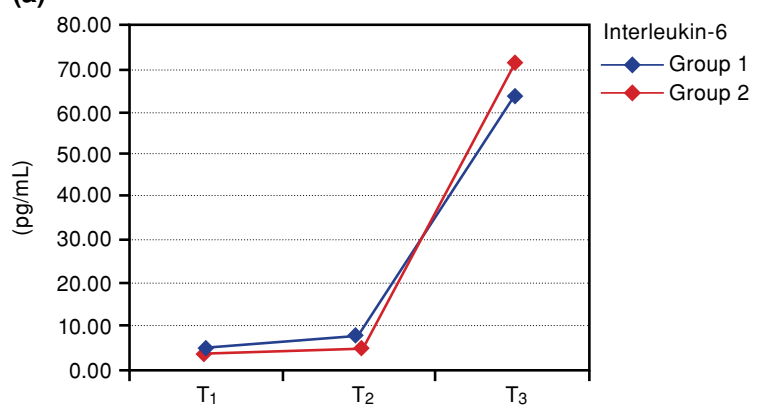

(c)

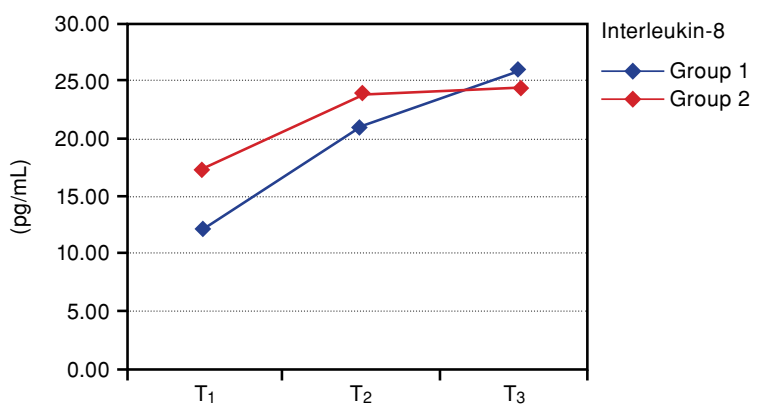

(b)

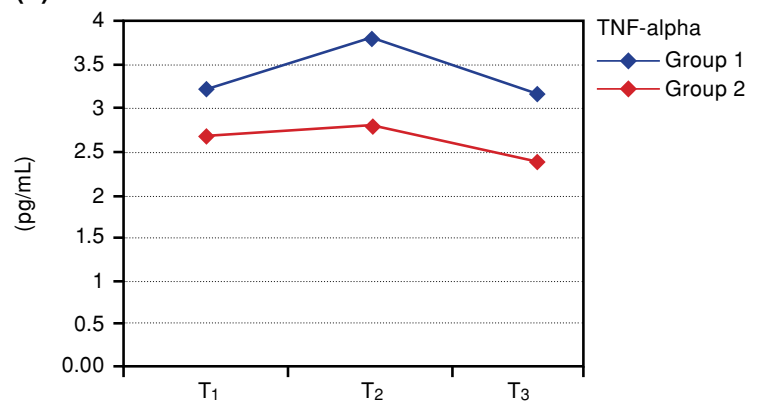

(d)

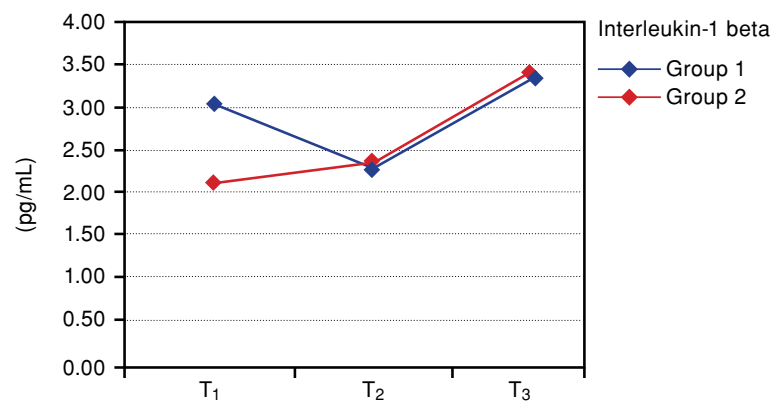

Figure 2. Mean levels of interleukin-6 (a), tumor necrosis factor-alpha (b), interleukin-8 (c), and interleukin-1 beta (d) in two groups achieved at three different time periods $\left(T_{1}, T_{2}\right.$, and $\left.T_{3}\right)$. TNF: Tumor necrosis factor. 


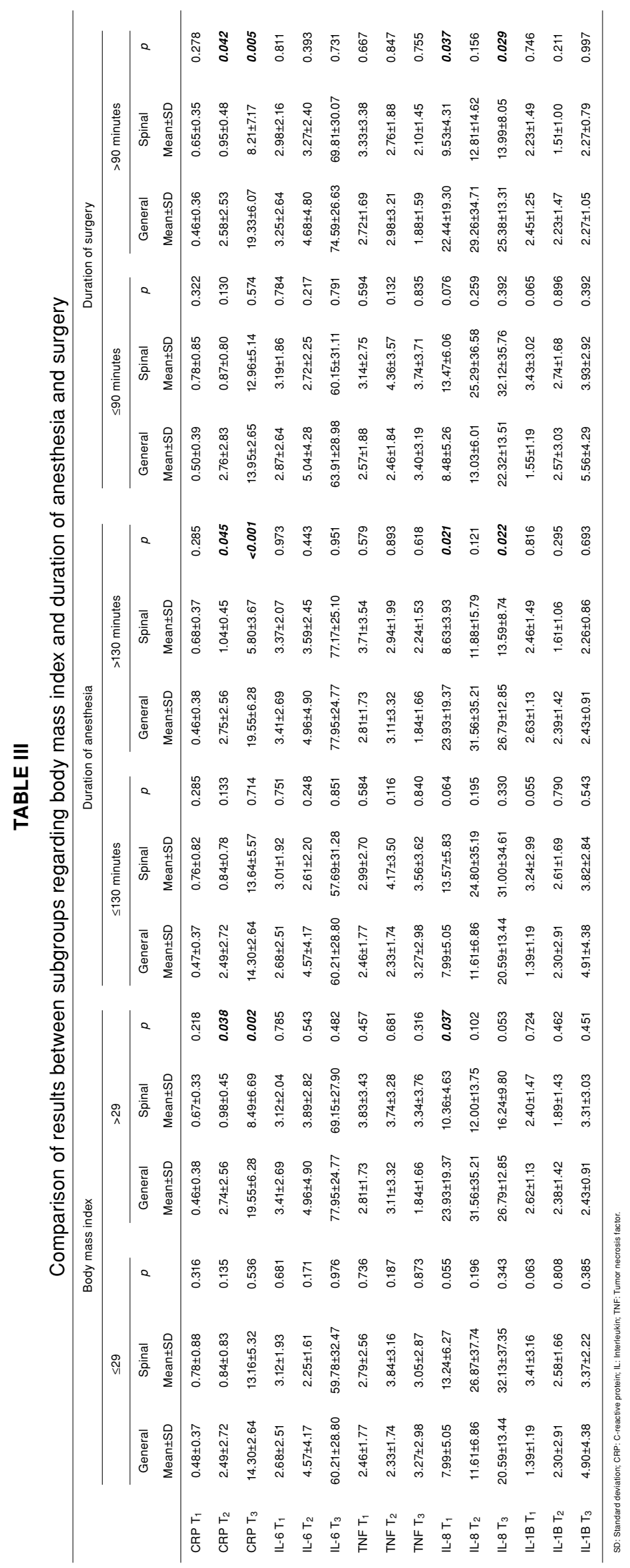


from $T_{1}$ to $T_{3}$ in both groups and decreased from $T_{2}$ to $\mathrm{T}_{3}$ (Figure 2). However, the change patterns were similar with no significant differences between the groups $(\mathrm{p}>0.05)$.

Level of TNF- $\alpha$ slightly increased from $T_{1}$ to $T_{2}$ and decreased from $T_{2}$ to $T_{3}$ in both groups. However, there were no significant differences between the groups (Table II).

Overall, no significant difference between the groups was observed in regard to the levels of CRP, IL-1 $\beta$, IL- 6 , IL- 8 , and TNF- $\alpha$ within the studied time period.

The groups were also divided into subgroups regarding body mass index ( $\leq 29$ vs. $>29)$ and duration of anesthesia ( $\leq 130$ minutes vs. $>130$ minutes) and surgery ( $\leq 90$ minutes vs. $>90$ minutes). Comparison of the subgroups indicated similar results. However, the only statistically significant differences between the subgroups were observed for CRP values obtained at $\mathrm{T}_{1}$ and $\mathrm{T}_{3}$ and for IL- 8 values obtained at $\mathrm{T}_{0}$ and $\mathrm{T}_{3}$, with higher values in group 1 (Table III).

\section{DISCUSSION}

The results of this study suggest that the level of SIR does not differ in terms of the anesthetic method after TKA. Any insult to the organism causes the host response including both local and systemic components. Anesthetic techniques used during perioperative period result in a SIR and suppression of cell-mediated immunity. ${ }^{[14]}$

Tissue damage emerging during surgery is the main factor in determining the level of SIR. ${ }^{[12]}$ It was previously reported that the changes in SIR were not different in regard to anesthetic method between the groups undergoing minor surgery. ${ }^{[15]}$ However, the effect of anesthetic methods on SIR following major surgeries have not been clarified. Decreasing excessive SIR after major surgeries, such as arthroplasty, by using appropriate anesthetic methods may provide clinical benefits. Although several studies investigated the effect of anesthetic methods on the SIR following various surgeries, ${ }^{[16-18]}$ to our knowledge, there are few studies to evaluate the effect of general and spinal anesthesia on SIR following TKA. ${ }^{[13]}$

Regional anesthesia, alone or in combination with general anesthesia, is used to provide satisfactory postoperative analgesia following major surgeries. However, the benefits of it regarding perioperative morbidity and mortality reduction and later outcomes (patients' rehabilitation and return to preoperative situation) are not fully clarified. Although the effect of regional anesthesia on the SIR was studied in some experimental models, there are few clinical studies with inconclusive results. Nonetheless, regional anesthesia can modulate SIR via various mechanisms at different levels following tissue injury. ${ }^{[14]}$ Hogevold et al. ${ }^{[13]}$ studied the effect of regional and general anesthesia in hip arthroplasty and, similar to our results, they reported that although the inflammatory markers (IL-6 and TNF- $\alpha$ ) increased postoperatively compared to the preoperative levels, there were no significant differences between the groups. Conrick-Martin et al. ${ }^{[19]}$ investigated the effect of spinal and epidural anesthesia vs. general anesthesia on natural killer T-lymphocytes and reported that the anesthetic methods seem not to effect postoperative natural killer T-lymphocyte functions. ${ }^{[19]}$

Tourniquet use may result in skeletal muscle ischemia-reperfusion injury, and thus increase the SIR to surgery. ${ }^{[20,21]}$ However, the mean time for tourniquet use were similar between the groups in this study.

Anesthetic methods used for minor and major surgeries would probably induce SIR of different levels. In a group of patients undergoing minor surgery, the levels of IL-2 were increased more in patients receiving general anesthesia compared to spinal anesthesia. However, no statistically significant difference was found in the levels of other proor anti-inflammatory cytokines after surgery under general or spinal anesthesia. ${ }^{[2]}$ The results of the present study revealed that the SIR was also similar following a major surgery.

This study has several limitations. First, only the pro-inflammatory cytokines were studied. Thus, we cannot comment on the changes in the levels of antiinflammatory cytokines. Second, we studied the levels of the cytokines only within 24 hours postoperatively. A longer study period might show different results.

In conclusion, this study indicated that TKA induces a postoperative SIR. Considering the levels of pro-inflammatory markers studied, the SIR is affected by the surgery itself and not by the drugs used in spinal or general anesthesia. Thus, we believe that the anesthesia method may not be used to overcome the adverse effects related to SIR following TKA.

\section{Declaration of conflicting interests}

The authors declared no conflicts of interest with respect to the authorship and/or publication of this article.

\section{Funding}

This study was supported by the Scientific Research Projects Coordination Unit of Afyon Kocatepe University, Turkey. 


\section{REFERENCES}

1. Eroğlu M, Er MS, Altınel L, Kokulu S, Yücehan M. The efficacy of subcutaneous local analgesic infusion in the early postoperative period after bilateral total knee arthroplasty. Eklem Hastalik Cerrahisi 2015;26:158-63.

2. Milosavljevic SB, Pavlovic AP, Trpkovic SV, Ilić AN, Sekulic $\mathrm{AD}$. Influence of spinal and general anesthesia on the metabolic, hormonal, and hemodynamic response in elective surgical patients. Med Sci Monit 2014;20:1833-40.

3. Orosz JE, Braz MG, Golim MA, Barreira MA, Fecchio D, Braz LG, et al. Cytokine profile in patients undergoing minimally invasive surgery with balanced anesthesia. Inflammation 2012;35:1807-13.

4. Alturfan AA, Tozun R, Emekli N. The evaluation of protein $\mathrm{C}$ activity and some inflammatory markers in synovia of patients undergoing total knee arthroplasty. Balkan Med J 2011;28:169-72.

5. Aghamir SM, Mojtahedzadeh M, Meysamie A, Atharikia D, Izadpanah F, Sheikhvatan M. Comparison of systemic stress responses between percutaneous nephrolithotomy (PCNL) and open nephrolithotomy. J Endourol 2008;22:2495-500.

6. Schricker T, Carli F, Schreiber M, Laftermann R, Georgieff M. Time of peritoneal cavity exposure influences postoperative glucose production. Can J Anaesth 1999;46:352-8.

7. Aksoy MS, Bozkurt M, Sayıt E, Ünlü S, Karadağ H. Does spinal anesthesia increase the pain and anxiety after total knee arthroplasty? a randomized prospective study. Eklem Hastalik Cerrahisi 2013;24:30-2.

8. Nishiyama T, Yamashita K, Yokoyama T. Stress hormone changes in general anesthesia of long duration: isofluranenitrous oxide vs sevoflurane-nitrous oxide anesthesia. J Clin Anesth 2005;17:586-91.

9. Homburger JA, Meiler SE. Anesthesia drugs, immunity, and long-term outcome. Curr Opin Anaesthesiol 2006;19:423-8.

10. Kelbel I, Weiss M. Anaesthetics and immune function. Curr Opin Anaesthesiol 2001;14:685-91.

11. Bar-Yosef S, Melamed R, Page GG, Shakhar G, Shakhar K, Ben-Eliyahu S. Attenuation of the tumor-promoting effect of surgery by spinal blockade in rats. Anesthesiology 2001;94:1066-73.

12. Grosu I, Lavand'homme P. Continuous regional anesthesia and inflammation: a new target. Minerva Anestesiol 2015;81:1001-9.
13. Høgevold HE, Lyberg T, Kähler H, Haug E, Reikerås O. Changes in plasma IL-1beta, TNF-alpha and IL-6 after total hip replacement surgery in general or regional anaesthesia. Cytokine 2000;12:1156-9.

14. Buyukkocak U, Daphan C, Caglayan O, Aydinuraz K, Kaya T, Saygun O, et al. Effects of different anesthetic techniques on serum leptin, C-reactive protein, and cortisol concentrations in anorectal surgery. Croat Med J 2006; $47: 862-8$.

15. Bravo-Cuéllar A, Romero-Ramos JE, Hernández-Flores G, Romo-Pérez Fde J, Bravo-Cuéllar L, Lerma-Díaz JM. Comparison of two types of anesthesia on plasma levels of inflammatory markers. Cir Cir 2007;75:99-105. [Abstract]

16. Schilling T, Kozian A, Senturk M, Huth C, Reinhold A, Hedenstierna $G$, et al. Effects of volatile and intravenous anesthesia on the alveolar and systemic inflammatory response in thoracic surgical patients. Anesthesiology 2011;115:65-74.

17. Yalcin S, Aydoğan H, Yuce HH, Kucuk A, Karahan MA, Vural M, et al. Effects of sevoflurane and desflurane on oxidative stress during general anesthesia for elective cesarean section. Wien Klin Wochenschr 2013;125:467-73.

18. Chloropoulou P, Iatrou C, Vogiatzaki T, Kotsianidis I, Trypsianis G, Tsigalou C, et al. Epidural anesthesia followed by epidural analgesia produces less inflammatory response than spinal anesthesia followed by intravenous morphine analgesia in patients with total knee arthroplasty. Med Sci Monit 2013;19:73-80.

19. Conrick-Martin I, Kell MR, Buggy DJ. Meta-analysis of the effect of central neuraxial regional anesthesia compared with general anesthesia on postoperative natural killer $\mathrm{T}$ lymphocyte function. J Clin Anesth. 2012;24:3-7.

20. Hughes SF, Hendricks BD, Edwards DR, Bastawrous SS, Roberts GE, Middleton JF. Mild episodes of tourniquetinduced forearm ischaemia-reperfusion injury results in leukocyte activation and changes in inflammatory and coagulation markers. J Inflamm (Lond) 2007;4:12.

21. Clementsen T, Reikerås O. Cytokine patterns after tourniquetinduced skeletal muscle ischaemia reperfusion in total knee replacement. Scand J Clin Lab Invest 2008;68:154-9.

22. Žura M, Kozmar A, Šakić K, Malenica B, Hrgovic Z. Effect of spinal and general anesthesia on serum concentration of pro-inflammatory and anti-inflammatory cytokines. Immunobiology 2012;217:622-7. 